\title{
The Study of Achievement and Motivation by e-Learning-A Case Study
}

\author{
Hong-Min Lin, Wan-Ju Chen, and Shu-Fen Nien
}

\begin{abstract}
With the rapid development of information systems and the Internet technology, there has been a lot of progress in the multi-media and the Internet industry. It has also brought innovation in the mode of educational learning. This study was designed for freshman students of college in the e-learning method of an accounting course, so as to investigate different achievement and motivation implementation of this method. The study applied quasi-experimental design, divided into an experimental group and a control group. Learning effect evaluation was done by using pre-test and post- test. In order to achieve the purpose of the study, the experimental group applied e-learning strategy and the control group applied traditional learning style. After a six week period, we examined the effectiveness of learning in the experimental group. The results were two-fold: firstly, e-learning strategy is not different from the traditional learning method in terms of achievement in accounting for freshman students in college; secondly, e-learning strategy is superior to the traditional learning method in terms of learning motivation.
\end{abstract}

Index Terms-E-learning, learning effectiveness, learning achievement, learning motivation.

\section{INTRODUCTION}

The fast development of information systems and the Internet technology not only makes a lot of progress in multi-media and the Internet industry, but it also affects innovation in the educational learning style. Because of technology development, e-learning will develop a particular learning style. Learner and educator will confront new teaching and learning methods [1]. In order to improve learning effectiveness, the government proposed the idea of a technology plan for National E-learning. Diversified content, learning experience and the Internet convenience will be accepted by schools nowadays.

The traditional learning style is based on a teacher as the center of learning and the classroom as the center of any learning activities. But, because information is rapidly spreading, and knowledge is renewing faster, the traditional learning style is no longer sufficient for learners. Computer

Manuscript received October 7, 2013; revised December 17, 2013.

Hong-Min Lin is with the Department of Special Education, National Taichung University of Education. No.140, Minsheng Rd., West Dist., Taichung City 40306, Taiwan R.O.C. (e-mail: tcivs2266@yahoo.com.tw).

Wan-Ju Chen is with the Department of Business Administration, Taiwan Shoufu University. No.168, Nanshih Li, Madou district, Tainan County 72153, Taiwan ROC and is also with the Department of Industrial Education and Technology, National Changhua University of Education No.2, Shi-Da Road, Changhua City 500, Taiwan R.O.C. (e-mail: post123465@gmail.com).

Shu-Fen Nien is with the Department of Industrial Education and Technology, National Changhua University of Education, No.2, Shi-Da Road, Changhua City 500, Taiwan R.O.C. (e-mail: f90312004@yahoo.com.tw). assistance learning with websites combines into The Internet learning. The learning method will improve one way or another from static to active. With e-learning, the learner and teacher can be in different places and interact at different times.

The teacher supplies learning content to learners via electronic flat screen or the Internet, and the learning activities for students are also done through the same form [2]. In e-learning, the teacher's role is guidance. Teachers are not in the role of explaining course content. And the learners become more active. Therefore, e-learning changes the responsibility of learning from teachers to learners. E-learning is participation learning which emphasizes the learner as prime. At the same time, e-leaning can provide students with an opportunity to learn how to learn, translation into lifelong learning, cooperation learning, and active learning. From the educational point view, the e-learning method is a new and fast way of the acquisition of knowledge, experience and skills. At present, every school plans to utilize e-learning advantages to develop students' desired learning content and provide students with a new way to learn.

As the above-mentioned shows, this study focuses on the different learning accounting methods of college freshman students to prove the variance in achievement and motivation of learning.

\section{THE RESEARCH PURPOSE}

This study investigates the following,

1) Application of e-Learning Method to a Traditional Learning Accounting Course.

2) If E-Learning of Accounting Course can Result in a Higher Learning Achievement.

3) if e-learning of accounting course can result in a higher learning motivation

This study also aims at,

1) Addressing Specific Suggestions about e-Learning.

\section{LITERATURE REVIEW}

\section{A. E-Learning}

E-learning can construct a new learning style through the Internet. E-learning is not restricted by space and time ; it provides individual multi-interaction, so it can make up for inadequacies of teaching activities in a traditional classroom [3], [4]. The definition of e-learning, the essence of e-learning is learning with the "e" as the only learning tool; that is the way of electronic learning, online learning or the Internet learning. Through the "e" learning method, learners 
can find understanding anytime and anywhere [5]. E-learning can be achieved through digital instruments - whether by computer, the Internet, satellite broadcast, compact disk or interactive TV [6]-[8].

E-learning will be in the mainstream of learning in the future and will create a lot of advantages [9]-[12]. The advantages are first, the source of learning is sharing so no more space limitation. Second, no more time limitation if the teaching platform server and the Internet channel function normally, which means learners can learn anytime online. Third, learning materials can be re-used over and over. Fourth, teachers can use multimedia to express the content meaning of e-learning. Fifth, e-learning is individual teaching and learning; the teacher can ascertain each learning situation so as to assist the learner. Sixth, e-learning can enhance learning interests because the teaching style is more active. In short, the advantages of e-learning are that learners can obtain more abundant and colorful materials and instructors can understand the focii and situation of learners.

Multi-media material contents illustrate the richness and diversification that combines sound, image, picture and motion picture, and words. The material contents of e-learning morph from static to active. E-learning sheds light on the diversified materials, assists learning and cognitive construction, provides suitable learning, enhances autonomy of learning, breaks through learning environment limitations, pushes resource-sharing and increases communication and interaction [13]. By importing the concept and technique of e-learning, and utilizing the characteristics of the Internet, multi-media interaction and personal learning process, can create a life-time learning model in which the learner is the center of activities and can study at anytime and anywhere [14].

\section{Methodology}

\section{A. Research Structure}

This is an experimental study. The students are divided into two groups-an experimental group and a control group. The variables include the students' ability and the teacher's ability. The independent variable is the effect of accounting e-learning. The dependent variable is the control group and experimental group with learning achievement and motivation at difference learning mode.

\section{B. Sample}

The study is based on a class at one private college and used as a unit. The study sample is a total of 31 students divided into two groups: 16 students are in the experimental group and 15 students are in the control group.

\section{Measurement}

The study applied quasi-experimental design that is division into the experimental group and control group. Learning effect evaluation was done using pre-test and post-test. In order to achieve the purpose of the study, the experimental group applied e-learning strategy and the control group applied traditional teaching style. The study proceeded for 6 weeks. The experimental design model is presented in Table I.
TABLE I: EXPERIMENTAL DESIGN MODEL

\begin{tabular}{cccc}
\hline group & pre-test & treatment & after-test \\
\hline $\begin{array}{c}\text { Experimental } \\
\text { group }\end{array}$ & $\mathrm{Y}_{1}$ & $\mathrm{X}$ & $\mathrm{Y}_{2}$ \\
\hline Control group & $\mathrm{Y}_{3}$ & -- & $\mathrm{Y}_{4}$ \\
\hline $\mathrm{Y}_{1}, \mathrm{Y}_{3}:$ pre-test & & & \\
$\mathrm{Y}_{2}, \mathrm{Y}_{4}:$ after-test & & & \\
$\mathrm{X}:$ treatment & & & \\
\hline
\end{tabular}

\section{E-Learning Systems}

This system was divided into three interfaces: students, teacher and administrator. The teacher interface is personal digital learning so the teacher is also the administrator. The explanation is as below:

\section{1) Student interface}

This system displays through the homepage. Students depending on their needs can review the static or active curriculum material. So students can watch the static curriculum and class information. Students can also watch the active curriculum, new announcements, personal grades, learning situation, and online test or exercise. The interaction which provides electronic notes and discussion is another way to have interaction between the teacher and learners.

\section{2) Teacher interface}

The system provides three functions including curriculum management, material management and online interaction. In curriculum management, the teacher can build system data, revise or check student information, and manage students' grades. Online teaching material provides teachers with diversified methods to design homework exercises. Online interaction provides discussion and communication between teacher and students in an asynchronous system. Online tests provide the teacher with a way to understand each student's learning situation.

\section{E. E-Learning Content Design}

According to Clark [15], the key to e-learning is not the media or technology, but the design strategy or what method is used in the media technology. The study applied ADDIE strategy, that is that the teacher should decide the learning goals, analyze the learners' capabilities and learning content, design the learning strategy and activities, develop material and media, implement learning, check the evaluation, and correct the comprehension in order to achieve the learning goal and allow for an acceptable learning effectiveness.

\section{F. Research Instrument}

This research tool includes e-learning material and three scale forms: basic ability scale form, the achievement scale form on the learning strategy for e-learning of accounting, and the motivation scale form on e-learning learning strategy.

\section{1) Basic ability scale form}

Each question includes two parts based on the ratio of different learning hours and the degree of curriculum involvement. The scale form is based on expertise validity.

\section{2) E-learning achievement scale form}

A learning achievement test is based on learning goals, material content and a learning hour ratio. Two detailed parts 
are based on the ratio of different learning hours and the degree of curriculum involvement. The scale form is based on expertise validity.

\section{3) Learning motivation scale form}

This scale form is based on literature review and refers to the learning motivation scale form of Keller and Ciou [16], [17]. According to our study needs, the first questionnaire draft was made. Moreover, six experts made a revision based on the first draft and an advisor verified it. Finally, the pre-test sample questionnaire was built by excellent expert validity. Pre-test applied consistent Cronbach $\alpha$ coefficient. The $\alpha$ coefficient of total questionnaire is 0.932 . The final pre-test questions were decided by principal component analysis, Eigen value is bigger than 1 and bigger than 0.3 of factor load is a significant load. Accumulated explanation variance is $59.045 \%$.

\section{G. Data Analysis}

In order to reach the purpose of study, the measurement is:

1) To analyze basic ability scale form depending on independent t-test based on mean and standard deviation.

2) To understand the differentiation of different styles for students learning accounting depending on ANCOVA and pre-test grades as covariance.

3) To understand the differentiation of different learning styles for students' motivation depending on ANCOVA and pre-test grade is covariance.

Those statistics are considered possible type I and type II error and the significance level of type I is .05.

\section{RESEARCH RESULTS}

\section{A. The Differentiation Analysis of Learning Achievement} of Different Learning Styles

\section{1) The differentiation analysis of basic ability (pre-test)}

Table II illustrates the descriptive data for the basic ability (pre-test) $t$-test analysis of each group. The data shows that it does not reach significance level $(t=1.825, p>.05)$. That means that the mean of basic ability test of these two groups does not make a difference.

TABLE II: THE SUMMARY OF BASIC ABILITy (PRE-TEST) T-TEST ANALYSIS

\begin{tabular}{ccccc}
\hline group & $\begin{array}{c}\text { number of } \\
\text { students }\end{array}$ & mean & $\begin{array}{c}\text { standard } \\
\text { deviation }\end{array}$ & t value \\
\hline $\begin{array}{c}\text { control } \\
\text { group }\end{array}$ & 15 & 57.266 & 12.109 & 1.825 \\
\hline $\begin{array}{c}\text { experimental } \\
\text { group }\end{array}$ & 16 & 64.437 & 9.702 & \\
\hline
\end{tabular}

2) The differentiation analysis of students' learning achievement of different learning strategies

Table III presents regression coefficient homogeneity that does not reach significance level $(F=3.333 p>.05)$. That means the slope of two teaching methods are the same. That matches the assumption of in-group regression coefficient homogeneity. Therefore, it can apply ANCOVA.
TABLE III: THE SUMMARY OF TWO LEARNING METHODS ON LEARNING ACHIEVEMENT REGRESSION HOMOGENEITY TEST

\begin{tabular}{ccccc}
\hline $\begin{array}{c}\text { the source of } \\
\text { variance }\end{array}$ & SS & DF & MS & F value \\
\hline $\begin{array}{c}\text { between } \\
\text { groups( regression } \\
\text { coefficient) }\end{array}$ & 16.693 & 1 & 16.693 & 3.333 \\
In-group(error) & 154.460 & 27 & 5.721 & \\
\hline
\end{tabular}

TABLE IV: THE SUMMARY OF TwO TEACHING METHODS ON LEARNING ACHIEVEMENT TEST COVARIANCE

\begin{tabular}{crrrr}
$\begin{array}{c}\text { the source of } \\
\text { variance }\end{array}$ & SS & DF & MS & F value \\
\hline between groups & 1.471 & 1 & 1.471 & 0.237 \\
\hline In-group(error) & 173.527 & 28 & 6.197 & \\
\hline
\end{tabular}

$* * p<.01$

Table IV explains covariance analysis results. After taking out the covariance of the effect of basis ability (pre-test grade), the two learning methods on learning achievement test do not reach significance level $(F=0.237, p<.05)$.

TABLE V: THE SUMMARY OF TWO LEARNING METHODS ON LEARNING AChiEvement Test Mean, Standard Deviation, And Mean AFTER ADJUSTMENT

\begin{tabular}{ccccc}
\hline group & $\begin{array}{c}\text { the number } \\
\text { of students }\end{array}$ & mean & $\begin{array}{c}\text { standard } \\
\text { deviation }\end{array}$ & $\begin{array}{c}\text { mean after } \\
\text { adjustment }\end{array}$ \\
\hline $\begin{array}{c}\text { control group } \\
\begin{array}{c}\text { experimental } \\
\text { group }\end{array}\end{array}$ & 15 & 61.933 & 13.630 & 65.786 \\
\hline
\end{tabular}

Table V shows analysis results. After taking out the covariance of the effect of basis ability (pre-test grade), the two learning methods on the learning achievement test show the same result for the experimental group of e-learning strategy (mean after adjustment $=65.326$ ) and for the traditional learning style (mean after adjustment $=65.786$ ).

\section{B. The Differentiation Analysis of Learning Motivation of Different Learning Strategies}

\section{1) The differentiation analysis of learning motivation (pre-test)}

TABLE VI: THE SUMMARY OF T-TEST OF LEARNING MOTIVATION

\begin{tabular}{ccccc}
\hline group & $\begin{array}{c}\text { the number } \\
\text { of students }\end{array}$ & mean & $\begin{array}{c}\text { standard } \\
\text { deviation }\end{array}$ & t value \\
\hline $\begin{array}{c}\text { control } \\
\text { group }\end{array}$ & 15 & 2.369 & 0.437 & 0.823 \\
$\begin{array}{c}\text { experimental } \\
\text { group }\end{array}$ & 16 & 2.487 & 0.361 & \\
\hline
\end{tabular}

Table VI shows two groups of descriptive data of pre-test of learning motivation. The data shows it does not reach significance level $(t=0.823, p>.05)$. That means that the mean of learning motivation test of these two groups does not reach 
significance level. So the learning motivation of these two groups before the experiment is not different.

2) The differentiation analysis of learning motivation of different teaching strategies

TABLE VII: THE SUMMARY OF THE TWO LEARNING METHODS ON LEARNING MOTIVATION POST-TEST REgRESSION HOMOGENEITY TEST

\begin{tabular}{ccccc}
\hline $\begin{array}{c}\text { the source of } \\
\text { variance }\end{array}$ & SS & DF & MS & F value \\
\hline $\begin{array}{c}\text { between } \\
\text { groups( regression } \\
\text { coefficient) }\end{array}$ & 0.003 & 1 & 0.003 & 9.836 \\
\begin{tabular}{c} 
In-group(error) \\
\hline
\end{tabular} & 0.149 & 27 & 0.006 & \\
\hline
\end{tabular}

Table VII shows that regression homogeneity test doesn't reach significance level $(F=9.836, p>.05)$. That means the slope of two learning methods are the same. That matches the assumption of in-group regression coefficient homogeneity. Therefore, it can apply ANCOVA.

TABLE VIII: THE SUMMARY OF Two LEARNING METHODS ON LEARNING MOTIVATION POST-TeST COVARIANCE ANALYSIS

\begin{tabular}{ccccc}
\hline $\begin{array}{c}\text { the source of } \\
\text { variance }\end{array}$ & SS & DF & MS & F value \\
\hline between groups & 1.236 & 1 & 1.236 & $170.533^{* *}$ \\
In-group(error) & 0.203 & 28 & 0.007 & \\
\hline$p<.05$
\end{tabular}

Table VIII explains covariance analysis results. After taking out the covariance of the effect of learning motivation (pre-test grade), the two learning methods on learning motivation after test reach significance level $(F=170.533$, $p<.01)$.

TABLE IX: THE SUMMARY OF Two TEACHING METHODS ON LEARNING

Motivation Test MeAn, StANDARD DEVIATION, AND MEAN AFTER ADJUSTMENT

\begin{tabular}{ccccc}
\hline group & $\begin{array}{c}\text { the number } \\
\text { of students }\end{array}$ & mean & $\begin{array}{c}\text { standard } \\
\text { deviation }\end{array}$ & $\begin{array}{c}\text { mean after } \\
\text { adjustment }\end{array}$ \\
\hline $\begin{array}{c}\text { control group } \\
\text { experiment } \\
\text { group }\end{array}$ & 15 & 2.369 & 0.437 & 2.436 \\
\hline
\end{tabular}

Table IX shows analysis results. After taking out the covariance of the effect of learning motivation (pre-test grade), the two learning methods on learning motivation after the test are that using experimental group e-learning strategy (mean after adjustment $=2.840$ ) is superior to using traditional narration (mean after adjustment $=2.436$ ).

\section{DISSCUSSION}

\section{A. The Learning Achievement Analysis of Different Groups}

The post-test results reveal that the learning achievement of experimental group and control group do not reach significance different level. That means the grades in the experimental group and control group are the same. This result echoes with relevant researches [18], [19] and is also similar to Song's research [20]. But this result is different from the results of Lin [21] and Chen's study [22]. The reason could be that in our study this is the first time for students to use e-learning, so they are not used to it. From dealing with the cognitive process view, listening is more salient than reading or speaking [23]. That means that students remember the information from listening easier than information from reading or narrating. Although the results of the two different learning styles don't reach a significant difference level, the empirical evidence proves that e-learning still matches the learning effect of traditional learning. However, e-learning should be taken seriously because e-learning works through sound, image and motion picture to enable learning and can be repeated in this way.

\section{B. The Learning Motivation Analysis of Different Groups}

The post-test results of experimental group and control group reveal that the learning motivation does reach a significance difference level. The experimental group grade is superior to the one of the control group. This result echoes with the relevant research carried out in Taiwan [24]. Similarly, Chen's [25] and Lin's research [21] pointed out that e-learning can enhance learning motivation. Syu and Jhang' results [26] also proved that different learning media had different learning motivation. The motivation of learning with the Internet is higher than the motivation of learning with a blackboard and projector. The presumed reason is that e-learning exists in a high interaction environment and multi-sense stimuli. Therefore, e-learning can enhance learning motivation.

\section{CONCLUSION AND SUGGESTION}

The conclusions of this study are that first, e-learning strategy is not different from traditional learning method at accounting learning achievement for freshman students in college. Second, e-learning strategy is superior to the traditional learning method at accounting learning motivation.

According to the conclusion of this study, we provide some suggestions: first, if students have computers and the Internet, they can learn anytime and anywhere, use materials repeatedly, and study the difficult part by themselves. Second, a college teacher should use e-learning strategy to strengthen students' learning motivation. Moreover, teachers should improve their skills in using e-learning strategy to enhance learning effectiveness. The school should have a plan for teachers to conduct e-teaching seminars or conferences and to invite e-learning experts to make speeches and demonstrations to enhance the teachers' capabilities and share experiences. In short, e-learning strategy facilitates student participation and communication. Therefore, teachers should develop e-teaching skills so as to encourage students in the use of e-learning activities.

In the future, continued research should focus on e-learning styles and receptiveness of students to the topic of e-learning. 


\section{REFERENCE}

[1] M. Y. Wang, "The assessment of the impact of elementary scientific education between e-learning teaching system and e-libraries,' National Science Council special study, no. 91-2520-S-364-001-X3, 2002.

[2] M. W. Jheng, "The exploration of distance education," Audio-Visual Education Bimonthly, vol. 41, no. 3, pp. 20-35, 1999.

[3] W. L. Shi, "Digital teaching strategies based on learning theory," Living Technology Education, vol. 40, no. 2, pp. 32-41, 2008.

[4] C. L. Hsu, "The Study of Computer Assisted Instruction and E-learning in Instructional Design Perspective in the Future," Educational Resources and Research, vol. 78, pp. 21-40, 2007.

[5] C. F. Chen, "The study on Scrom-Based adaptive learning model for the Learning Management System designed," Unpublished education dissertation, National Taichung Teachers College, 2004.

[6] S. Y. Syu, "The exploration of curriculum development model of e-learning," Journal of Education Research, vol. 116, pp. 15-30, 2003.

[7] J. K. Liao. (2004). Learn digital opinion. [Online]. Available: http://www.elearn.org.tw/elnp/eNews/eL_Insight_002.htm

[8] K.-L. Eva. (October 10, 2005). Learning circuit: Glossary. [Online]. Available: http://www.learningcircuits.org/glossary.html

[9] R. H. Huang, "The functions and standards of e-learning management system," Information and education, vol. 89, pp. 21-22, 2002.

[10] J. C. Yan, "The influential factors in the e-learning of junior high school students," Unpublished education dissertation, National Kaohsiung Normal University, 2005.

[11] S. Russ, "10 Reasons E-Learning Is a Successful Training Tool," Multi-Housing News, vol. 38, pp. 24, 2003.

[12] W. K. Horton, Designing web-based training-How to teach anyone anything anywhere anytime, New York: John Wiley Et Sons, 2000.

[13] M. H. Rossman. (June 22, 2006). Successful online teaching using an asynchronous learner discussion forum. [Online]. Available: http://www.aln.org/publications /jaln/v3n2/v2n2_rossman.asp

[14] G. E. Jhang, "The research of technology plans of national e-learning and e-learning integration of cross-field," Journal of Education Research, vol. 125, pp. 126-132, 2004.

[15] R. E. Clark, "Media will never influence learning," Educational Technology Research \& Development, vol. 42, no. 2, pp. 21-29, 1994.

[16] J. M. Keller, "Motivational design of instruction," Instructional design theories and models: an overview of their current status, Hillsdale, N. J.: Lawrence Erlbaum, pp. 384-434, 1987.

[17] H. F. Ciou, "The research of the impact of Multimedia interface among learning motivation, learning achievements and study reservations for elementary school students," unpublished education dissertation, National Pingtong Teachers College Institute of Technology, 2003.

[18] W. J. Ma, "The research of e-learning teaching in mathematics of first-grade high school students in Kaohsiung," Unpublished education dissertation, National Kaohsiung Normal University Institute of Mathematics Education, 2003.

[19] R. Gerver, "The effects of a certain type of mathematics simulation on the attitude, achievement, attendance and punctuality of ninth-grade remedial mathematic student," Unpublished doctoral dissertation, New York University, New York, 1990.

[20] M. J. Song, "The study of network interactive multimedia supportive teaching practice in mathematics field of the impact between learning effectiveness and learning attitude," Unpublished education dissertation, Fu Guang University Institute of Information Education, 2004.

[21] C. Lin, "The research of e-learning system to implement remedial teaching," Unpublished education dissertation, National Kaohsiung Normal University, Institute of information Education, 2003.

[22] M. C. Chen, "The study of comparison to the learning effect between network interactive multi-media teaching and traditional teaching -case by commercial departments," Instructional Technology \& Media, vol. 63, pp. 49-64, 2003.

[23] J. Preece, Y. Roger, and H. Sharp, Interaction design: Beyond human-computer interaction, New York: John Wiley \& Sons Press, 2003.

[24] W. C. Lin, "The study of network interactive multimedia supportive teaching practice in elementary mathematics field of the impact between learning effectiveness and learning attitude," Unpublished education dissertation, National Hsinchu Teachers College Mathematics Education, 2004.

[25] L. H. Chen, "Research on Learning Effects of Information Technology Integrating Social Science Teaching," Unpublished education dissertation, National Ping tong Teachers College Institute of National Education, 2003.

[26] J. L. Syu and Y. F. Jhang, "The exploration of the relationship between Characteristics of the media teaching materials and learning motivation of students," Journal of Education Research, vol. 116, pp. 64-76, 2003.

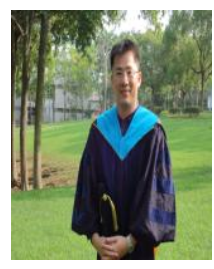

Hong-Min Lin was born on May 8, 1973, Taiwan. He is a Ph.D of Department of Industrial Education and Technology at National Changhua University of Education in Changhua city, Taiwan, R.O.C. He is a teacher at Taichung Industrial Vocation School and part-time associate professor in the department of special education at National Taichung University of Education, Taiwan. He has published in ICIC Express Letters, An International Journal of Research and Surveys. His research interests include instruction of special education, e-learning and career education.

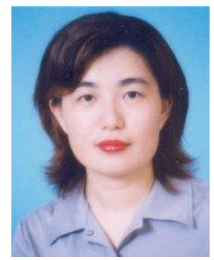

Wan-Ju Chen was born on April 5, 1967, Taiwan. She is a Ph.D candidate of Department of Industrial Education and Technology at National Changhua University of Education in Changhua city, Taiwan, R.O.C. She is a lecturer in Business Administration Department at Taiwan Shoufu University, Taiwan. She has published in ICIC Express Letters, An International Journal of Research and Surveys. Her research interests include intellectual capital, knowledge management, human research management, e-learning and education.

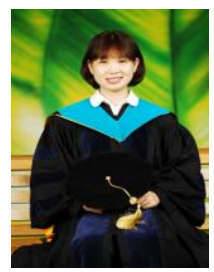

Shu-Fen Nien was born on Jan. 7, 1975, Taiwan. She is a $\mathrm{Ph}$. D candidate of Department of Industrial Education and Technology at National Changhua University of Education in Changhua city, Taiwan, R.O.C. She is a teacher at National Beidou Senior Home Economic and Commercial Vocation High School in Taiwan. She has published in ICIC Express Letters, An International Journal of Research and Surveys. Her research interests include leadership of principal, positive psychological capital, e-learning and education. 